\title{
Challenges to decentralisation in the Democratic Republic of the Congo: Beyond the political settlement
}

\author{
Niamh Gaynor $^{1}$ \\ School of Law and Government \\ Dublin City University \\ Glasnevin \\ Dublin 9 \\ Ireland \\ T: 00-353-1700-6048 \\ E: niamh.gaynor@dcu.ie
}

Keywords: Democratic Republic of Congo; decentralisation; conflict; liberal peacebuilding; political settlement

Acknowledgements: This work was supported by grants from Dublin City University, the Royal Irish Academy and Trócaire. The author would also like to thank Léa Valentini, Carol Ballantine, Christine Mansiantima, Guylain Lukalansoni, Dieudonné Nzita and Julie Bavuma for logistical assistance for her fieldwork in Bas-Congo.

\footnotetext{
${ }^{1}$ Niamh Gaynor is a lecturer in the School of Law and Government in Dublin City University, Ireland where she specialises in politics and development in Sub-Saharan Africa. She is the author of Transforming participation?: The Politics of Development in Malawi and Ireland (Palgrave Macmillan, 2010) and has published in a wide range of journals including the Review of African Political Economy; Journal of Southern African Studies; Development Policy Review; Globalizations; Politics and Society; Development in Practice; and the Community Development Journal.
} 


\title{
Challenges to decentralisation in the Democratic Republic of the Congo: Beyond the political settlement
}

\begin{abstract}
Decentralisation is increasingly seen as an important part of conflict resolution and peacebuilding strategies within fragile states where increased public accountability and participation help reduce horizontal inequalities and address local grievances. This view assumes a strong political element to decentralisation however. Drawing on fieldwork conducted in Kinshasa and in Bas-Congo, this article highlights three key sets of challenges to political decentralisation in the Democratic Republic of the Congo (DRC) which arise from its roots within the elite political settlement. A re-orientation in support is proposed providing for a deeper political decentralisation and a more inclusive political settlement.
\end{abstract}

\section{Introduction}

Widespread international support for decentralised governance since the late 1980s has resulted in its adoption in over 80 per cent of developing countries to date (Crawford and Hartmann, 2008). Perceived as offering a wide range of benefits - from increased efficiency and effectiveness of public service provision to increased state legitimacy, stability and support (Crook, 2003; Smoke, 2003; Devas and Delay, 2006) - decentralisation has also, more recently, come to be seen as an increasingly important part of conflict resolution and peacebuilding strategies within fragile states where its potential to transform politics and political relations may reduce horizontal inequalities and the causes of grievance (Cammack et al, 2006; DfID, 2006; Brinkerhoff, 2011; World Bank, 2011). Contributions at this level emphasise the political nature of decentralisation and highlight the key inter-related elements of downward accountability and citizen participation in decentralised structures and processes. 
The Democratic Republic of the Congo (DRC) is no exception to this trend. Adopted as part of the new Constitution in 2006, decentralisation has been hailed by international donors, local non-governmental organisations and academic commentators alike as offering the opportunity to democratise and transform politics, to reduce horizontal inequalities and to promote social cohesion and stability at local levels (UNDP, 2007; World Bank, 2007; Engelbert and Tull, 2008; Liègeois, 2009; Wedi Djamba, 2012). Yet, progress in the DRC has been torturously slow. The territorial re-division of the country - planned to take place by 2009 - has not happened. Local elections have yet to take place. And the financial aspect of the decentralisation programme - retention of 40 per cent of revenue generated within each province - also remains stalled.

Examining the reasons for this apparent impasse, this article highlights three principle sets of challenges to the process - resistance from central authorities; weaknesses in the relevant legislation; and a lack of responsiveness to local priorities at provincial level. It argues that these challenges are due to decentralisation being rooted in the post-war elite political settlement of the early 2000s which privileged regional stability over political transformation. Consequently, decentralisation in the DRC is limited to territorial reform and therefore differs fundamentally from the more politically transformative forms reviewed in the literature and pursued in neighbouring states. Moving toward a more inclusive political settlement, a reorientation in donor support is proposed - thinking beyond elections as a means toward political transformation to more regularised fora of debate and exchange between citizens and their local authorities. Drawing on both documentary and field research conducted in 2013 
and 2014 in the country's capital, Kinshasa and across 12 diverse sites in the resource-rich Bas-Congo province in the West of the country ${ }^{2}$, the argument is developed as follows.

The following section provides a brief account of the country's political history, providing an overview of the context into which decentralisation was introduced. This account draws on critiques of the liberal peacebuilding model promoted by international actors to highlight the manner in which it has increased the marginalisation, vulnerability and insecurity of the population. The specific obstacles to the roll-out of the process are presented in the third section and challenges at a national level are discussed. Section four turns to an analysis of the legislation and policy underpinning the decentralisation reforms and, comparing these with those in the neighbouring countries of Burundi and Rwanda where decentralisation has also been introduced as part of peacebuilding strategies, highlights the limited opportunities afforded by the Congolese process for political reform and transformation. The fifth section then turns to an analysis of the effectiveness of decentralisation in Bas-Congo province where findings reveal a lack of downward accountability and responsiveness toward citizens together with low levels of public trust in and high levels of animosity towards provincial authorities and politics more broadly. The article concludes with a discussion of the implications of the findings for international donors and supporters of the process.

\footnotetext{
${ }^{2}$ Field research was conducted in 2013 and 2014 in the country's capital, Kinshasa and across 12 diverse sites (selected to reflect variety across urban and rural settings; socio-economic contexts; and levels of low-lying conflict) in the resource-rich Bas-Congo province in the West of the country. Research included semistructured interviews with eight national and provincial ministry officials, seven national and provincial nongovernmental organisation (NGO) representatives, and eight international donor representatives. In addition, research in Bas-Congo province included semi-structured interviews with 103 randomly selected residents (51 female; 52 male), 24 focus groups ( 12 female, 12 male, each with between 8-12 participants) and nine semistructured interviews with local authorities. Focus group and interview transcripts were coded following the fieldwork and the data was processed through SPSS to allow for some descriptive statistical analysis.
} 


\section{The role of decentralisation following 'Africa's world war'}

The so-called 'Congo wars' of the 1990s and their aftermath are widely regarded as some of the most complex and egregious conflicts of our time. Rooted in a violent international political economy of extraction and exploitation and involving eight foreign armies together with up to twenty local militia groups, the conflict has generated levels of suffering that are unparalleled in any recent war and have caused, directly and indirectly, the highest death toll of any conflict since World War II ${ }^{3}$. Following a number of unsuccessful peace processes throughout the 1990s, in late 1999 the United Nations (UN) began to deploy a small observatory force - the UN Mission in Congo (MONUC) to oversee a cease-fire agreement signed by all warring parties some months previously. With the beginnings of an uneasy stability within the country and region more broadly ${ }^{4}$, the UN's peacekeeping role grew considerably and its Congolese Mission, at $\$ 8.7$ billion, now represents the largest and most expensive operation in the UN's history (Englebert and Tull 2008; Eriksen 2009; Trefon 2013). The peacebuilding approach employed in the DRC mirrors the dominant model employed more widely with its emphasis on a political settlement involving powersharing among elites, the promotion of liberal democratic institutions, and security sector reform. A transitional government overseen by President Joseph Kabila and four Vice-Presidents representing the four principle warring factions was established in July 2003; a new Constitution was adopted in early 2006; elections for the national Presidency and for national and provincial assemblies took place in 2006 with national elections again taking place in 2011; and efforts have been made to integrate former armed combatants into the national army.

\footnotetext{
${ }^{3}$ It is beyond the scope of this article to present an overview of the events and impacts of this conflict. For excellent, comprehensive and insightful overviews see Autesserre, (2010, Chpt 2) and Prunier (2011).

${ }^{4}$ While some stability was restored in Kinshasa and other parts of the country, violence continued in the Eastern and North-Eastern provinces.
} 
Decentralisation also formed part of this peacebuilding programme. Enshrined within the new Constitution and further developed through legislation prepared in 2008, it provided for a new territorial division of the country (from the existing 11 provinces) into 25 provinces and the City of Kinshasa. The province was now to become a political and administrative component in its own right managed by local authorities. The provincial assembly was to become the legislative body, elected by direct universal suffrage for a 5-year term, and the provincial government the executive body. The Governor and Vice-Governor were to be elected for a 5-year term, renewable once by provincial members of parliament within or outside of the provincial assembly, and to be appointed by order of the national President. Forty per cent of all revenue generated within each province was to be retained within the provinces. Provinces were to be further divided into Decentralised Territorial Entities (ETDs) - to include cities, communes, sectors and traditional "chefferies" (chiefdoms). These were also to be governed by elected councils.

Thus, the decentralisation programme, conceived as part of a broader internationallysanctioned political settlement, provided for a re-distribution of power and resources across and within provinces. Yet, despite a number of key events aimed at advancing the process ${ }^{5}$, progress, as with the peacebuilding approach employed more broadly, has been torturously slow. Why so? The growing consensus on weaknesses within the broader peacebuilding approach within which decentralisation is embedded sheds some light on this question. Two

\footnotetext{
${ }^{5}$ Generally driven by provincial authorities and/or international donor agencies, these have included the Declaration of Matadi in 2007 where provincial assembly members called for implementation of the $40 \%$ financial provision; a National Forum in 2007 bringing state, provincial, donor and civil society leaders together to agree the main steps in rolling out the process; adoption of the relevant legislative texts in 2008; the publication of a Strategic Framework for the Implementation of Decentralisation (CSMOD) in 2009; and a National Forum on the Transfer of Competencies in 2012 where agreement was reached on the transfer of competencies in four ministries - health, education, agriculture and the environment.
} 
key weaknesses have been identified in this regard. First, it is argued that the elite level focus of the peacebuilding approach - focused on obtaining an elite political settlement - has strengthened the power of rebels and combatants, thereby increasing the vulnerability and insecurity of the population (Engelbert and Tull 2008; Eriksen 2009; Marriage 2011). Second, it is argued that peacekeepers and peacebuilders, in focusing primarily on macrolevel structures and actors, have failed to address the local drivers and structural causes of conflict (Kisangani 2006, 2010; Engelbert and Tull 2008; Trefon 2011; Larmer et al 2013). These critiques are pertinent in relation to decentralisation where, as we will see, its key challenges arise from its roots in the elite macro-level political settlement and its attendant neglect and marginalisation of local communities. This is evident in the delays, obstructions and obfuscations surrounding the process; in the ambiguity and political weakness of policy and legislation underpinning it; and in the priorities of investment and activity at provincial level together with popular attitudes towards provincial and sub-provincial level leaders more broadly. We turn to the first of these issues below.

\section{Challenging decentralisation: Resistance from the centre}

As one commentator notes ${ }^{6}$, there is a lot of talk but very little concrete action around decentralisation, with strong resistance in particular from authorities in Kinshasa.

There are a lot of forums around decentralisation that say "yes, we want the process to move". But on the ground, in practice, it's not really moving. So there is this push from the Provinces but the centre is not really opening the doors. So this is where the agenda of decentralisation is really lost.

\footnotetext{
${ }^{6}$ Interview, international donor agency representative, January 2013. 
There is widespread agreement among interviewees in both Kinshasa and Bas-Congo ${ }^{7}$ that the key issue underpinning this resistance is access to and control of resources. From their side, central authorities in Kinshasa are said to maintain control over the distribution of power and the vast natural resource wealth in Bas-Congo province through a system of patronage networks ${ }^{8}$. As Mayamba (2012: 44) notes, 'In the Bas-Congo, the authorities [in Kinshasa] collude with business interests in a web of nepotistic networks that control of vast swathe of the province's resources.'. This is greatly facilitated by the fact that many of the key provincial positions such as the heads of army, police, customs and the land ministry are occupied by authorities from Kinshasa ${ }^{9}$. At provincial level, Bas-Congolese provincial authorities are at the forefront of the so-called 'retrocession' debate - calling for the retention of 40 per cent of provincial resources within the province as set out in Constitutional Article 175. More recently, following significant obstacles and delays, the Bas-Congolese succeeded in gaining control of the Provincial Governership as locally elected Jacques Mbadu ousted Kinshasa's favourite Déo Nkusu who, Vice-Governor since 2003 and Acting-Governor following the election of the sitting Governor to national parliament, rejected the outcome of provincial elections ${ }^{10}$. Notwithstanding this victory, the new Governor is now reported to also be in Kinshasa's pocket ${ }^{11}$.

Resistance from Kinshasa is also manifest in a number of additional ways. These include delays in the preparation of additional legislation deemed necessary for the process to progress; delays in holding local ETD-level elections leaving Kinshasa the power to nominate

\footnotetext{
${ }^{7}$ Interviews with ministry officials, national NGOs and international agencies supporting decentralisation, January and February 2013; January 2014.

${ }^{8}$ Interviews national NGO and international donor representatives, Kinshasa, January 2013; January 2014.

${ }^{9}$ Interviews NGO representatives Matadi and Tshela, February 2013; see also Mouflet 2009 and Tull 2010 on this.

${ }^{10}$ See http://radiookapi.net/actualite/2012/10/31/ffrttyyyjijkkllmmmm/ for more background on this.

${ }^{11}$ Interviews NGO representatives from Matadi, Boma and Tshela, January 2014.
} 
local officials ${ }^{12}$; ongoing debate and disputes about the proposed new provincial divisions; the incorporation of the Ministry of Decentralisation, in May 2012, into the Ministry of the Interior which is focused on national control and cohesion as opposed to any form of devolution; and amendments to Articles 197 and 198 of the Constitution, introduced in January 2011, which give new powers to the national President to dissolve the Provincial assembly or dismiss a Provincial Governor in the event of a "serious, menacing political crisis" in the province. In addition, no progress has been made over the last five years on the administrative aspect of decentralisation. The Ministry responsible, the Ministry of Public Services has had six different Ministers over the last five years ${ }^{13}$. The consequence is that, while provinces have a provincial government and assembly, there is no functional provincial administration. The only progress in this regard is the ongoing development (since 2011) of an intermediary public finance management mechanism which, supported by the World Bank and UNDP, is currently being piloted in a number of provinces. Moreover, as Trefon (2010) and Englebert (2012) both demonstrate, local administrations are very often unable and indeed unwilling to work towards reform. In the atmosphere of uncertainty surrounding decentralisation, where the 'privatisation' of public service provision serves to compensate for poor levels of official remuneration, local officials are more likely to undermine administrative reforms rather than facilitate them. Prospective reforms at this level are further hampered by the apparent ambiguity of international donors towards administrative capacity and reform (see Moshonas, 2013).

\footnotetext{
12 The planned 2011 provincial elections did not take place either and deputies elected for a five year term in 2006 continue to hold their seats.

${ }^{13}$ Interview ex-Ministry official, January 2013. 
Taken together, these issues are all symptomatic of the fact that decentralisation has its roots in the elite political settlement negotiated in the early 2000s and continues to be understood by key actors involved as an institutional battleground for resources between political elites at national and provincial level. As such, it lacks the politically transformative dimension underpinning decentralisation initiatives elsewhere where the potential to transform political and social relations is actualised through specific procedures and practices. This is evidenced at a policy level in the following section which compares relevant policy and legislation with that of neighbouring Burundi and Rwanda - countries which have both adopted decentralisation as a strategy to mitigate against further conflict and promote democracy, equity and social stability across the region.

\section{Challenging decentralisation: Legislative and policy weaknesses}

In the DRC, as in many countries where decentralisation has been introduced, details of structures and procedures for the new reforms are embedded in a specific set of local government laws ${ }^{14}$. In this section relevant legislation and policy in the DRC is compared to that of Rwanda and Burundi where decentralisation was also introduced as part of peacebuilding efforts in 2000 and 2005 respectively. While an analysis of policy and legislation is limited in two principle respects - first, it is a relatively weak gauge of national policy due to the high levels of donor influence in its elaboration, and second, what is reflected in policy is generally vastly different to its application on the ground - it is useful to our purposes here in that it provides a sense of the underlying spirit and ethos of the decentralisation projects across the three jurisdictions. Paying particular attention to the provisions and opportunities for political decentralisation across these three cases we find

\footnotetext{
${ }^{14}$ Weaker legal frameworks involve a simple central government policy or a central decree (Thede, 2009)
} 
that, although all three programmes are rooted in visions of political transformation and local democracy, significant differences exist in relation to policies and practices of accountability and participation across each case. The Burundian and Rwandan processes correspond more closely to what the European Commission has characterised as a political 'new wave of decentralisation', with its emphasis on principles of participation, transparency and accountability (Europe Aid, 2007), while the Congolese process, lacking these principles, is more redolent of the top-down decentralisation model of both the colonial and Mobutu eras.

The overall aim of decentralisation, as set out in the guiding policy for each country, is as follows. Within the DRC the aim is broad and all-encompassing, with the key guiding issues being human development, local democracy and conflict prevention.

'The end result of the implementation of decentralisation is to contribute to the promotion of sustainable human development and the prevention of risks of conflict. It also involves the creation of better conditions of development and a rooting of local democracy.' (RDC, 2009, p.30)

The analogous Rwandan policy (GoR, 2001), succinctly capturing the inter-related problems of previous decentralised regimes, is more focussed, highlighting issues of poverty reduction and local community participation as core objectives.

'The overall objective of the decentralisation policy is to ensure political, economic, social, managerial/administrative and technical empowerment of local populations to fight poverty by participating in planning and management of their development process.' (GoR, 2001, p.8). 
Burundi's decentralisation policy is explicitly rooted in the country's past conflict and decentralisation is discussed in terms of a new political culture, according citizens a central role in the process.

'...Decentralisation aims at the active participation of all the population in defining and implementing economic and social development policies in their localities. The envisaged outcomes from a process of Decentralisation are, on the one hand, local and community development and, on the other, local democracy and good governance.' (GdB, 2009, p.10)

Thus, while all three countries root their respective programmes within a political context, Rwanda and Burundi's programmes place particular emphasis on local political participation and development and are thus more focused - in policy terms at least - on the politically transformative potential of the process.

Moving to a comparison of provisions set out in the relevant legislation for each programme, further differences between each country's programme are revealed in the levels of clarity and detail in relation to the functioning of local, decentralised institutions set out in the relevant texts. Taking some basic procedures and practices within the more local (and thereby publically accessible) institutions, Table 1 below compares and contrasts these across the three jurisdictions. 
Table 1: The structure and functioning of local, decentralised institutions in the DRC, Rwanda and Burundi

\begin{tabular}{|c|c|c|c|}
\hline & DRC & Rwanda & Burundi \\
\hline Local structures & $\begin{array}{l}\text { Province (x26) } \\
\text { ETD (town, commune, } \\
\text { sector/chiefdom) }\end{array}$ & $\begin{array}{l}\text { Province (4) - to be } \\
\text { abolished } \\
\text { District (x30) } \\
\text { Sector (x416) } \\
\text { Cells } \\
\text { Villages }\end{array}$ & $\begin{array}{l}\text { Province (17) } \\
\text { Commune (129) } \\
\text { Hills }\end{array}$ \\
\hline $\begin{array}{l}\text { No. members on } \\
\text { local council }\end{array}$ & Not stated & $30-40$ at district level & $\begin{array}{l}15 \text { at commune } \\
\text { level } \\
5 \text { at village level }\end{array}$ \\
\hline $\begin{array}{l}\text { Member } \\
\text { selection process }\end{array}$ & $\begin{array}{l}\text { Elections but unclear what } \\
\text { type (direct / indirect) for } \\
\text { ETD as these have not yet } \\
\text { taken place. }\end{array}$ & $\begin{array}{l}\text { - Indirect elections at district, } \\
\text { sector and cell levels. } \\
\text { - Direct elections at village } \\
\text { level } \\
-30 \% \text { gender quotas } \\
\text { throughout plus special } \\
\text { interest nominees }\end{array}$ & $\begin{array}{l}\text { - Elected through } \\
\text { block party lists at } \\
\text { commune level. } \\
\text { - Directly elected } \\
\text { as individuals at } \\
\text { hill level. }\end{array}$ \\
\hline $\begin{array}{l}\text { Frequency of } \\
\text { meetings }\end{array}$ & Not stated & $\begin{array}{l}\text { District council meets } 4 \\
\text { times a year. }\end{array}$ & $\begin{array}{l}\text { Commune council } \\
\text { meets } 3 \text { times a } \\
\text { year, a quorum of } \\
10 \text { is required. }\end{array}$ \\
\hline $\begin{array}{l}\text { Decision making } \\
\text { processes }\end{array}$ & $\begin{array}{l}\text { Not stated. } \\
\text { ETD decisions are sent } \\
\text { upward to the provincial } \\
\text { Governor who can over- } \\
\text { rule these. } \\
\end{array}$ & Not stated & $\begin{array}{l}\text { Majority system - } \\
\text { open or secret } \\
\text { ballots employed. }\end{array}$ \\
\hline $\begin{array}{l}\text { Accountability } \\
\text { mechanisms }\end{array}$ & $\begin{array}{l}\text { - ETD meetings should be } \\
\text { public although members } \\
\text { can request private } \\
\text { meetings. } \\
\text { - Proceedings of } \\
\text { deliberations should be } \\
\text { published in the annals of } \\
\text { the respective council. It is } \\
\text { not stated who these are } \\
\text { made available to. } \\
\text { - No mention of budget } \\
\text { reporting }\end{array}$ & $\begin{array}{l}\text { - District meetings should be } \\
\text { public although members can } \\
\text { request private meetings. } \\
\text { - Proceedings of } \\
\text { deliberations are filed in the } \\
\text { district office - citizens can } \\
\text { request to see these although } \\
\text { they can be refused. } \\
\text { - Budgets are not made } \\
\text { public } \\
\text { - Accountability upward } \\
\text { assured through reward- } \\
\text { based performance contracts. }\end{array}$ & $\begin{array}{l}\text { - Commune } \\
\text { meetings are } \\
\text { public. } \\
\text { - Proceedings of } \\
\text { deliberations are } \\
\text { posted on a notice } \\
\text { board outside the } \\
\text { commune office. } \\
\text { - Budget is } \\
\text { approved by the } \\
\text { provincial } \\
\text { Governor and then } \\
\text { posted on the } \\
\text { notice board. }\end{array}$ \\
\hline $\begin{array}{l}\text { Participation } \\
\text { mechanisms }\end{array}$ & Not stated & $\begin{array}{l}\text { At village level through } \\
\text { community meetings with } \\
\text { local authorities (once a } \\
\text { month). }\end{array}$ & $\begin{array}{l}\text { Commune } \\
\text { councillors meet } \\
\text { hill representatives } \\
\text { and community } \\
\text { groups twice a } \\
\text { year. }\end{array}$ \\
\hline
\end{tabular}

Sources: RDC, 2008; GoR, 2005, 2006; GdB, 2005, 2011 
Within the DRC, details on the structure and functioning of ETD level councils and fora are set out in the Law on the structures and functions of ETDs (RDC, 2008). Provision is made for the three types of elected councils - at town, commune and sector and/or chiefdom levels. As noted previously, elections for these councils have yet to take place and ETDs are currently administered by centrally appointed authorities. The relevant law contains no details on the number of council members or on the form of election (direct or indirect) of members of each. It is not stipulated how often council meetings should take place and the form of decision-making to be employed (open/closed ballot or consensus) is also not noted. In terms of accountability, accountability upwards to the provincial Governor is emphasised, with council decisions subject to being over-ruled by the Governor at his ${ }^{15}$ discretion. Mechanisms for downward accountability are more ambiguous with the possibility of closed council meetings included, and no specific provision for public access to proceedings from these meetings or information on ETD budgetary provisions and decisions. No mechanisms for public participation in council meetings or interaction with members are included.

In contrast, more detail and precision in relation to these key mechanisms is included in the analogous laws for Rwanda and Burundi's programme. Burundi's laws are particularly detailed and clear in this regard. In Rwanda, members at the most local level (village) are directly elected, with members at higher levels (cell, sector and district) being indirectly elected from among these. A 30 per cent gender quota is in place at all levels. In Burundi, members at the most local level (hill) are also directly elected and commune level elections are also direct although, being from party lists of candidates rather individuals, they tend to be heavily manipulated and politicised (interviews CSO representatives, Bujumbura, September 2011). The frequency of meetings at each level in each jurisdiction is clearly set

\footnotetext{
${ }^{15}$ None of the current Provincial Governors are women (UNDP, 2011b).
} 
out, although only the Burundian legislation sets out the decision-making processes to be used. Upward accountability in Rwanda is consolidated through performance-based contracts whereas in Burundi, budgetary approval by the Governor is required. The Rwandan mechanisms of downward accountability appear relatively weak and comparable to those of the DRC. In contrast, clear mechanisms are set out in Burundi, where both proceedings of council meetings and local budgets are required to be posted publically on notice boards located outside council buildings. In contrast to the DRC's lack of legislative provisions, mechanisms for local community participation are set out in both Rwandan and Burundian legislation in the form of monthly community meetings in Rwanda and bi-annual meetings between commune councillors and hill residents in Burundi.

Overall, comparison of the legislative underpinnings of decentralisation programmes in the three jurisdictions reveals fundamental differences in the politically transformative potential of the Congolese process vis-à-vis those of its two neighbours, with specific mechanisms for downward accountability and community participation more developed in Burundi and

Rwanda. As the following section, which moves to focus to decentralisation at provincial level, demonstrates, these legislative and policy weaknesses inevitably carry over into political behaviours and practices on the ground.

\section{Challenges at a provincial level: Predatory politics and popular frustration in Bas-Congo province}

So far we have seen that the obstacles to a truly politically transformative form of decentralisation emanate from central authorities in Kinshasa. Many commentators (e.g. Marysse 2005; Liègeois 2009; Barrios and Ahamed 2010; Ngoma-Binda et al 2010; Tull 
2010 and Wedi-Djamba 2012) either implicitly and explicitly make the case for greater autonomy at provincial levels where local authorities, they argue, being closer to communities, will be more responsive to their needs. The findings presented in this section, which draw from field research conducted across 12 diverse sites in Bas-Congo province call into question this argument. The findings highlight both a lack of responsiveness of provincial authorities to local people's priorities and a corresponding lack of public trust in these authorities.

Bas-Congo province in Western DRC, with a population of approximately 4.5 million, is the country's smallest province although, within the proposed new 26 provincial configuration, it is the largest mono-ethnic one ${ }^{16}$. It makes for an interesting case as, endowed with vast levels of natural resources (diamonds, gold, bauxite, phosphate, rock salt, oil shale, manganese, marble, alluvium), it is the second wealthiest province in the country (Liégeois, 2009: 11). Bas-Congo is also the country's only oil-producing area, producing three billion barrels per annum with an estimated one billion barrels of reserves. According to the International Crisis Group (2012), Bas-Congo is financially more important to the country than Katanga due to its high level of oil production, although disputes are ongoing over offshore exploitation blocks between Kinshasa and Luanda (Trefon 2013, 148). Oil generated more than $\$ 320$ million in tax revenue for the country in 2010, the most recent year for which figures are available (EITI 2012, 32). Bas-Congo is also the site of the vast Inga hydroelectric dam which has been billed as having the power to electrify the entire continent ${ }^{17}$. There is a railway line between Matadi and Kinshasa and the country's only ports, Matadi, Boma and

\footnotetext{
${ }^{16}$ Unlike elsewhere, the existing territorial boundaries of the province have been retained within the (contested) new territorial reconfiguration.

${ }^{17}$ See http://biofreshblog.com/2011/11/23/dr-congo-and-south-africa-sign-pact-to-implement-40000-mw-grandinga-dam/; see also Showers (2009).
} 
Banana, through which nearly all manufactured goods reach Kinshasa, are located in the Province (ADB 2009).

This wealth notwithstanding, poverty is widespread in the province, with a poverty rate of 70 per cent reported five years ago (ADB, 2009). In focus groups and interviews of randomly selected residents conducted for this research 95 per cent of research participants, with negligible differences between women and men although a slightly higher level of rural than urban respondents, claimed that life is worse today than a generation ago. Within focus groups and interviews, research participants highlighted three key issues as current priorities - economic insecurity, food insecurity and personal insecurity - the latter notably for young women and girls. The most pressing issue cited was the rapidly escalating cost of living combined with little or no remunerated job opportunities leaving many families struggling to meet their basic necessities. The logging companies which provided much employment and prosperity during the colonial era gradually fell into decline, ultimately closing down following the nationalisation programme introduced in 1973, and leaving many families struggling to eke out a living in agriculture. Public sector salaries are low and unreliable for example a primary school teacher earns approximately US $\$ 50$ per month, yet even this is sporadic and unreliable. Routine expenses are considerably higher. For example in Matadi, the provincial capital, rent for a regular family house with intermittent and unreliable services (water and electricity) is $\$ 30$ per month. Meanwhile, it costs $\$ 75$ a month for just the basic foodstuffs to feed an average six-member family ( $\$ 40$ for a 50 kilogram bag of maize meal and $\$ 35$ for a similar weight of Fufu meal). On top of that, with teachers' salaries often unpaid for months on end, all schools require 'fees', reported to vary between $\$ 20$ to $\$ 40$ per trimester. Basic healthcare services, although available, prove unaffordable to many. 
The second major issue cited by research participants was food insecurity. This is caused by high land rents (approx. \$20-25 per annum for an average 0.25 hectare plot) and falling land fertility due to both overproduction and increasingly erratic weather patterns linked to climate change. Almost all individuals interviewed (95 per cent) across the 12 sample sites grow food - some at subsistence level and some to sell also. This is predominantly women's work and, with plots generally located about five kilometres from main settlements to avoid theft, much time and energy is spent travelling to and fro on foot, toting heavy baskets of produce and tools. There is no agricultural advisory service, there are no oxen or tractors and no specialist inputs are available. Research participants report extremely poor harvests (approximately 50 per cent germination rates), in part due to poor soil fertility, and in part to escalating climatic perturbations as the effects of climate change are increasingly felt. Consequently, food shortages are common. Indeed, a recent study (Savy Sunda et al 2011, p.36) shows that hunger is widespread in the province with 60 per cent of households surviving on two meals a day and a further nine per cent on just one meal a day.

The third most pressing issue raised is the escalation of personal insecurity, notably genderbased violence and rape. Gender-based violence in the DRC is pervasive and takes many forms. While the under-reporting of such incidents makes data on this extremely inaccurate, one report claims that 35 per cent of women and children have suffered sexual violence; 43 per cent emotional violence and 57 per cent physical violence (UNDP, 2011b, p.28). 45 per cent of interviewees in this described incidents of rape in their communities and noted that it is very much on the increase. This is ascribed to poverty and hunger (of young women and girls), together with a breakdown in public morality. 
Discussing the reasons for these changes, the blame is laid squarely at the feet of the provincial authorities. An overwhelming sense of frustration with and a lack of faith in current institutions is palpable as individuals explain that provincial authorities care only for their own interests and are neither willing nor capable of bringing the much needed employment and factories back to the region. Some excerpts from focus group discussions provide a flavour of these sentiments.

'It's a problem of Directors [those that govern], in the level of the Provincial Government. The money comes but it never comes to the base. The Directors of this country work for their families only... Before they were honest, now they lie, they are selfish.'

(Participant female focus group, Mayunda)

'The money that they [Provincial Deputies] get in the Province office over there, it's to send their children to school and to live well... All the money they get, it's for their own lives, to go to Europe etc. They don't care a bit about us.'

(Participant, female focus group, Ntomba3)

'It's the bad faith of our leaders... If you go to Congo-Brazzville there is no problem. There are leaders there of a good faith, of good hearts, and the population who live in good conditions. It is not the people from Brazzaville who come here. It is us who go to live there because of our misery.... What do you want? A [Provincial] deputy at 9,000 dollars but the carpenter has 30 dollars or 50 dollars [monthy salaries]. This divide - it's huge. It's too much.'

(Participant, male focus group, Soyo)

This antipathy towards provincial, as opposed to national or international authorities appears due to both the relative proximity of Provincial leaders to local populations - most candidates embarked on extensive campaigns (tellingly termed 'propagandas' in the DRC) through villages during the election season where many promises were made of which little has subsequently materialised - and the 'civic education' campaigns of local civil society groups 
around these elections ${ }^{18}$. Unlike in the East of the country, international actors are very positively viewed in Bas-Congo where people retain a nostalgia for what they perceive to be the heyday of colonial rule where, focus group participants report, international mining and logging companies provided near full employment. Concrete evidence for popular frustrations with Provincial authorities is found by comparing communities' priorities as set out above and those of Provincial authorities as outlined in the Provincial Action Plan (PAP) (GP, 2011) where a clear mismatch in priorities is apparent. As outlined above, the findings from field research across the 12 sites indicate that the three areas of economic, food and personal insecurity are the principle priorities of local communities. An analysis of the PAP however reveals relatively low levels of support in these areas, yet high levels of investment in the systems and structures of rent extraction - governance structures themselves and mining. These priorities are echoed in interviews conducted with both the Provincial Minister of the Interior and Cabinet Directors in the Governor's office ${ }^{19}$.

The PAP is a comprehensive plan setting out all the programmes the provincial government envisages for the province over the 5 year time frame 2011-2016. Given the lack of transparency around Assembly debates and decision-making, together with the lack of documentation in this respect, it is the sole document which provides some indication of provincial government policy. Comprising four pillars, it includes figures on overall budgets, budgets secured and funding sources (state, province or other funders). While the overall budgets for different programmes do not necessarily give an indication of priority (as certain activities simply cost more than others), the percentage of provincial spending for secured

\footnotetext{
${ }^{18}$ Interviews local NGOs, Matadi and Tshela, February 2013.

${ }^{19}$ Interviews conducted in January 2013 in Kinshasa and in February 2013 in Matadi, Bas-Congo province respectively.
} 
budgets potentially does ${ }^{20}$. Specifically, a 100 per cent spend is taken here to indicate a high priority while a 0 per cent spend is taken to indicate a low or non-existent priority.

Of the four pillars set out in the PAP, 'Good governance and peace promotion' has secured the most funding ( 80 per cent of its overall budget). Within this, the highest provincial spend (100 per cent funding from the province) is on 'improvements in administrative governance' while there is a 0 per cent spend on 'local development promotion' and 'justice and security'. The second pillar, 'Economic diversification, growth acceleration and jobs promotion' - one of clear relevance to communities - has secured just 37 per cent of its overall budget. The provincial government is focusing its resources in two areas - 'systems management' and 'improving mining revenues'. While the latter area may provide some local jobs, given the extractive patterns seen elsewhere in the country, it is unlikely to bring any significant benefits to local communities. Contrarily, the two areas attracting no provincial support are the 'development of provincial industries' and the 'development of local tourism' - both of which have significantly more capacity to generate local employment - a core priority for local communities.

The third pillar, 'Improvements in access to social services and human capacity building', has secured 43 per cent of its overall budget, with provincial resources focused in the somewhat arbitrary areas of 'sport and leisure activities', the 'valorisation of provincial cultural patrimony' and 'the improvement of rural habitat'. Meanwhile, social welfare programmes including 'social protection for widows and orphans', 'protection for children

\footnotetext{
${ }^{20}$ Although this may also be influenced by the willingness of other sources (state and external funders) to contribute also. However, a fuller analysis of the data (conducted by the author but not included here due to space constraints) reveals that the Province has committed to full (100 per cent) funding of some programmes yet no ( 0 per cent) funding of others which have attracted no funds from elsewhere either, thereby indicating that some priorities are identified independent of other funders at provincial level.
} 
and vulnerable groups' and 'assessment of HIV impact' are receiving no provincial funding. Finally, the fourth pillar, 'Protection of the environment and fight against climate change'again, a clear priority for communities facing falling and failing harvests, has secured just one per cent of its overall budget, and all provincial resources are focused on adaptation rather than mitigation strategies, together with risk management in the event of environmental disasters. Taken together, the findings from the PAP analysis appear to reinforce the perceptions of focus group participants and individual interviewees - that provincial authorities appear more focused on personal enrichment and resource extraction than on the needs and exigencies of their constituents.

Overall, the analysis presented in this section reveals both a low level of responsiveness and effectiveness of provincial structures vis à vis community needs and correspondingly predominantly negative public perceptions of political authorities and their motivations. This potent combination of predatory politics and local frustration and anger poses a significant threat to political stability and does not auger well for future development within this, one of the wealthiest yet, for many, poorest provinces in the country.

\section{Conclusion: Toward a more inclusive political settlement}

While, as noted in the introduction, decentralisation is now widely seen as an increasingly important component of peacebuilding strategies in fragile states, there is still no strong empirical basis for this view. Indeed, a number of large-N studies focusing on the impact of decentralisation in post-conflict situations indicate that it leads to increased rather than reduced conflict (Lake and Rothchild, 2005; Schou and Haug, 2005; and Siegle and O’Mahoney, 2008) although the reasons for this are not known. This article makes a contribution in this regard. Highlighting three principle challenges to political 
decentralisation in the Congolese context, it argues that these arise because decentralisation is rooted in an elite political settlement which, aimed at regional stability, has strengthened the power of former rebels and combatants at both national and provincial levels thereby increasing the vulnerability and marginalisation of the population. This argument is evidenced through an examination of the specific obstacles as identified by key actors in the field, a comparison of relevant legislation across the DRC, Rwanda and Burundi, and through an analysis of provincial authority responsiveness and effectiveness in Bas-Congo province.

Looking to the future, it is clear that addressing the challenges and deepening decentralisation requires a move beyond the current political settlement to a more inclusive one which engages marginalised factions and groups. It requires moving therefore, beyond the popular donor institutionalist perspective focused on elections and state capacities toward a more relational approach which explicitly recognises the socially embedded character of states and state authorities. Hickey's recent (2013) conceptualisation of 'adapted political settlements' is perhaps useful in this regard in that, moving beyond the "narrow frame of methodological nationalism" (Hickey, 2013, p. 14) which tends to privilege the role of elite actors, it seeks to capture the broader range of practices and factors that shape the politics of development, together with the broader range of actors in any given context. Following this more inclusive approach, Hickey argues that three additional factors need to be considered within political settlements - the role of ideas (as well as interests); the agency of marginalised, subordinate groups and communities; and the agency of transnational as well as national factors.

What this means in the context of the DRC's decentralisation programme is thinking beyond elections as a means toward political transformation to more regularised fora of debate and 
exchange between citizens and their local authorities where ideas and aspirations around a more transparent, equitable and sustainable use of resources are negotiated. Bearing in mind that state capacity is a function of negotiations, agreements, and power relations between and among political constellations of actors and that angry, excluded factions - such as those developing in Bas-Congo - can threaten the elite political order, regularised fora such as those set out in the legislation underpinning decentralisation in Burundi and Rwanda, can provide a platform for exchange of and deliberation on ideas and local development plans as well as, as noted within the Rwandan and Burundian policies, countering the marginalisation and exploitation experienced by disenfranchised groups.

Clearly the challenges to moving beyond the political settlement and building and supporting deeper and more inclusive governance mechanisms are significant. But so too are the dangers in not doing so. As all in the Great Lakes region know, history has proven that it is a grave mistake to ignore local frustrations and tensions. These can build and manifest into major violence and conflict destabilising entire regions and peoples. Greater attention by all, including the international donor community, to the more transformative potential of decentralised governance might well be one step towards attaining greater stability and development within the region. 


\section{Bibliography}

ADB 2009. Regional Economic development in Bas Congo in the Context of Decentralisation in the Democratic Republic of Congo (DRC). Country Operations Department Centre Region (ORCE): African Development Bank.

Autesserre S. 2010. The Trouble with the Congo: Local Violence and the Failure of International Peacebuilding, Cambridge University Press: Cambridge and New York.

Barrios C, Ahamed CS. 2010. Democracy promotion vs. state-building: decentralisation in the Democratic Republic of Congo, ECPR conference: Stockholm.

Brinkerhoff DW. 2011. State Fragility and Governance: Conflict Mitigation and Subnational Perspectives, Development Policy Review 29(2): 131-153.

Cammack D, McLeod D, Menocal AR, Christiansen K. 2006 Donors and the 'Fragile States' Agenda: A Survey of Current Thinking and Practice. Overseas Development Institute:

London.

Crawford G, Hartmann C. 2008. Decentralisation in Africa: A Pathway out of Poverty and Conflict?. Amsterdam University Press: Amsterdam.

Crook RC. 2003. Decentralisation and Poverty Reduction in Africa: The Politics of LocalCentral Relations. Public Administration and Development 23(1): 77-88.

Devas N, Delay S. 2006. Local Democracy and the Challenges of Decentralising the State. Local Government Studies 32(5): 677-695.

DfID. 2006. Eliminating World Poverty: Making Governance Work for the Poor: White Paper on International Development Department for International Development: London.

EITI 2012. Initiative pour la Transparence des Industries Extractives: RDC, Report 2010. Kinshasa, KPMG/CTB/GIZ.

Englebert P, Tull DM. 2008. Postconflict Reconstruction in Africa: Flawed Ideas about Failed States. International Security 32(4): 106-139.

Englebert, P. 2012 Incertitude, Autonomie et Parasitisme: Les Entités Territoriales Décentralisées et l'État en République Démocratique du Congo. Politiques Africaine 125: 169-188.

Eriksen SS. 2009. The Liberal Peace Is Neither: Peacebuilding, State building and the Reproduction of Conflict in the Democratic Republic of Congo, International Peacekeeping 16(5): 652-666.

Europe Aid. 2007. Supporting Decentralisation and Local Governance in Third Countries. Europe Aid Tools and Methods Series Reference Document No. 2. European Commission: Brussels. 
GdeB. 2005. Loi no. 1/016 du 20 avril 2005 portant organisation de l'administration communale. Gouvernement de Burundi: Bujumbura.

GdeB. 2009. Document de Politique Nationale de Décentralisation au Burundi. Gouvernement de Burundi : Bujumbura.

GdeB. 2011. Manuel de Procédures Administratives et Financières. Gouvernement de Burundi: Bujumbura.

GoR. 2006. Law No. 08/2006 of 24/02.2006 determining the organisation and functioning of the District. Republic of Rwanda: Kigali.

GoR. 2005. Law No. 29/2005 of 31/12/2005 determining local administration entities. Republic of Rwanda: Kigali.

GoR. 2001. National Decentralisation Policy. Republic of Rwanda: Kigali.

GP. 2011. Programme d'Actions Prioritaires (PAP) du Plan Quinquennal Provincial de Croissance et de l'Emploi 2011-2015. Gouvernment Provincial: Province du Bas-Congo, RDC.

Hickey S. 2013. Thinking about the politics of inclusive development: towards a relational approach. ESID Working Paper No. 1; Effective State and Inclusive Development Project; Manchester University: Manchester.

International Crisis Group. 2012. Black Gold in the Congo: Threat to Stability or Development Opportunity?. International Crisis Group, Africa Report No. 188.

Kisangani EF. 2006. Legacies of the war economy in M. Nest, F. Grignon \& E.F Kisangani, eds., The Democratic Republic of the Congo: Economic dimensions of war and peace. New York: International Peace Academy.

Kisangani EF. 2010. Civil Wars in the Democratic Republic of the Congo: 1960-2010, Lynne Rienner: Boulder, Colorado.

Lake DA, Rothchild D. 2005. Territorial decentralisation and civil war settlements. In Sustainable peace: Power and democracy after civil wars. Roeder PG, Rothchild D. (eds.). Cornell University Press: Ithaca, New York.

Larmer M, Laudati A, Clark JF. 2013. Neither war nor peace in the Democratic Republic of the Congo (DRC): profiting and coping amid violence and disorder. Review of African Political Economy 40(135): 1-12.

Liégeois M. 2009. Acteurs et enjeux du processus de decentralisation. Réforme au Congo: Attentes et désillusions. Trefon T. (ed.). Harmattan: Paris.

Marriage Z. 2011. Divisive "Commonality": state and insecurity in the Democratic Republic of the Congo. Third World Quarterly 32(10): 1891-1910.

Marysse SL. 2005. Decentralisation Issues in Post-Conflict Democratic Republic of the Congo. l'Afrique des Grands Lacs Annuaire 2004/2005. 
Moshonas S. 2014. The Politics of Civil Service Reform in the Democratic Republic of the Congo. Journal of Modern African Studies 52(2): 251-276.

Mouflet, Véronique. 2009. 'Le Bas-Congo, aux marges de l'agenda international, Angles morts sur les émeutes de 2008', Afrique contemporaine, 232 : 57-74.

Ngoma-Binda P, Otemikon Mandefu Yahisule J, Moswa Mombo, L. 2010. République Démocratique du Congo: Démocratie et participation à la vie politique. Open Society Initiative for Southern Africa (OSISA) : Johannesburg.

Prunier G. 2011. From Genocide to Continental War: the 'Congolese' Conflict and the Crisis of Contemporary Africa.Hurst and Co.: London. ( $2^{\text {nd }}$ ed.).

RDC. 2008. Loi organique $n^{\circ}$ 08/016 du 07 octobre 2008 portant composition, organisation et fonctionnement des Entités Territoriales Décentralisées et leurs rapports avec l'Etat et les Provinces, Journal Officiel de la République Démocratique du Congo. Cabinet du Président de la République : Kinshasa.

RDC. 2009. Cadre Stratégique de la Mise en Oeuvre de la Décentralisation (CSMOD). Ministère de la Décentralisation et Aménagement du Territoire : Kinshasa

Savy Sunda K, Mvubu N, Balomba M, Lukombo M, Mufuta D. 2011. Rapport final de l'étude de base sur la vulnérabilité et les moyens alternatifs de survie des ménages et organisations paysannes, Trócaire : Kinshasa.

Schou A, Haug M. 2005. Decentralisation in conflict and post-conflict situations. Working Paper 139. Norwegian Institute for Urban and Regional Research: Oslo.

Siegle J, O’Mahony P. 2008. Assessing the Merits of Decentralisation as a Conflict Mitigation Strategy. Paper prepared as part of USAID's study to the revision of the Decentralisation and Democratic Local Governance Programming Handbook. USAID: Washington.

Smoke P. 2003. Decentralisation in Africa: Goals, Dimensions, Myths and Challenges. Public Administration and Development. 23(1): 7-16.

Thede N. 2009 Decentralization, Democracy and Human Rights: A Human Rights-based Analysis of the Impact of Local Democratic Reforms on Development. Journal of Human Development, 10(1): 103-123.

Trefon T. 2013. Uncertainty and powerlessness in Congo 2012. Review of African Political Economy. 40(135): 141-151.

Trefon T. 2011. Congo Masquerade: The Political Culture of Aid Inefficiency and Reform Failure. Zed Books: London and New York.

Trefon T. 2010. Administrative obstacles to reform in the Democratic Republic of the Congo. International Review of Administrative Sciences. 76(4): 702-722. 
Tull DM. 2010. Troubled state-building in the DR Congo: the challenge from the margins. Journal of Modern African Studies. 48(4): 643-661.

UNDP. 2011a. Rapport National du Développement Humain 2010: La Décentralisation et la Gouvernance Démocratique face à l'impératif du développement humain, PNUD/United Nations Development Programme: Kinshasa.

UNDP. 2011b. Rapport National Genre, PNUD/ United Nations Development Programme: Kinshasa.

UNDP. 2007. Document de Programme de pays pour la République Démocratique du Congo, 2008-2012. PNUD/United Nations Development Programme: Kinshasa.

Wedi Djamba D. 2012. Bread and Peace for the Democratic Republic of the Congo: Is Decentralisation the Answer? LAP LAMBERT Academic Publishing: Saarbrücken, Germany

World Bank. 2011. Conflict, Security and Development: World Development Report 2011 World Bank: Washington.

World Bank 2007. International Development Association Country Assistance Strategy for the Democratic Republic of the Congo for the period FY08-FY11. World Bank: Washington. 